OPEN ACCESS

Edited by:

Marta Álvarez,

Oceanographic Center of Vigo, Spain

Reviewed by:

Ingeborg Bussmann,

Alfred Wegener Institute Helmholtz Centre for Polar and Marine Research

(AWI), Germany

Jun Sun,

Tianjin University of Science and Technology, China

*Correspondence:

Yong Zhang

yongzhang@sdu.edu.cn;

zhangyong6111@163.com

Wei-dong Zhai

wdzhai@126.com

Specialty section:

This article was submitted to

Marine Biogeochemistry,

a section of the journa

Frontiers in Marine Science

Received: 25 November 2019

Accepted: 31 January 2020

Published: 21 February 2020

Citation:

Zhang Y, Chen B and Zhai W

(2020) Exploring Sources

and Biogeochemical Dynamics of Dissolved Methane in the Central

Bohai Sea in Summer.

Front. Mar. Sci. 7:79.

doi: 10.3389/fmars.2020.00079

\section{Exploring Sources and Biogeochemical Dynamics of Dissolved Methane in the Central Bohai Sea in Summer}

\author{
Yong Zhang*, Bing Chen and Wei-dong Zhai* \\ Institute of Marine Science and Technology, Shandong University, Qingdao, China
}

To clarify the sources and biogeochemical dynamics of dissolved methane $\left(\mathrm{CH}_{4}\right)$ in shallow-water coastal oceans, we investigated the concentrations, sea-to-air fluxes, and net cycling rate of $\mathrm{CH}_{4}$ in the central Bohai Sea in summer 2018. During the survey, both summertime stratification and dissolved oxygen (DO) deficit were observed. In the surface layer, $\mathrm{CH}_{4}$ concentration $\left(\left[\mathrm{CH}_{4}\right]\right)$ ranged from 3.08 to $10.27 \mathrm{nmol} \mathrm{kg}^{-1}$. The average sea-to-air flux was estimated at $6.46 \pm 3.32 \mu \mathrm{mol} \mathrm{m}-2 \mathrm{~d}^{-1}$, indicating that the Bohai Sea serves as a source of atmospheric $\mathrm{CH}_{4}$. In the bottom layer, $\left[\mathrm{CH}_{4}\right]$ ranged from 4.29 to $31.04 \mathrm{nmol} \mathrm{kg}^{-1}$. The downward increase in $\left[\mathrm{CH}_{4}\right]$ within the water column indicated substantial sources of $\mathrm{CH}_{4}$ in the seafloor. Based on the complex relationship between the saturation ratio of $\mathrm{CH}_{4}$ and $\mathrm{DO}$, three types of $\mathrm{CH}_{4}$ release from the seafloor were identified, including diagenesis of buried organic matter, natural leakage from geological settings, and anthropogenic release from offshore oil/gas development. The saturation ratios of $\mathrm{CH}_{4}$ in bottom waters were positively correlated with the degree of stratification of the water column. Using a two-layer box model, sedimentary $\mathrm{CH}_{4}$ release rates at two oxygen-deficient stations were estimated to be 56.0-60.8 $\mu \mathrm{mol}$ $\mathrm{m}^{-2} \mathrm{~d}^{-1}$, which was much higher than the sea-to-air fluxes. The modeling results also indicated that the majority of seafloor released $\mathrm{CH}_{4}(>90 \%)$ was consumed in the water column of this shallow-water coastal sea. This is the first comprehensive study on $\mathrm{CH}_{4}$ cycling in the Bohai Sea. This work shows the indicative role of DO in identifying multiple $\mathrm{CH}_{4}$ sources and highlights the dominance of water stratification and microbial consumption in local $\mathrm{CH}_{4}$ dynamics.

Keywords: methane, sea-to-air flux, microbial consumption, dissolved oxygen, stratification, Bohai Sea

\section{KEY POINTS}

- Dissolved $\mathrm{CH}_{4}$ exhibited complex relations with oxygen in the Bohai Sea.

- Three types of $\mathrm{CH}_{4}$ sources from seafloor were identified.

- Stratification hampered the upward transport of dissolved $\mathrm{CH}_{4}$.

- Strengths of $\mathrm{CH}_{4}$ cycling terms are quantified. 


\section{INTRODUCTION}

Over a century time scale, the global warming potential of methane $\left(\mathrm{CH}_{4}\right)$ is 28 times greater than that of carbon dioxide (IPCC, 2013). Since the beginning of the industrial period, the atmospheric mole fraction of $\mathrm{CH}_{4}$ has increased by 2.5 times, contributing $\sim 17 \%$ of global warming (WMO, 2017). Global $\mathrm{CH}_{4}$ emissions are estimated at $\sim 558 \mathrm{Tg} \mathrm{CH}_{4} \mathrm{yr}^{-1}$ (Saunois et al., 2016), while global oceans release $\mathrm{CH}_{4}$ to the atmosphere only at a rate of less than $2 \mathrm{Tg} \mathrm{CH}_{4} \mathrm{yr}^{-1}$ (Rhee et al., 2009). Although the oceanic contribution to global $\mathrm{CH}_{4}$ emission is minor (likely $<0.5 \%$ ), it is significant compared with the average source-sink imbalance of $6 \mathrm{Tg} \mathrm{CH}_{4} \mathrm{yr}^{-1}$ (i.e., the atmospheric $\mathrm{CH}_{4}$ growth rate) in the 2000s (Kirschke et al., 2013). About two-thirds of the global oceanic emissions are contributed by coastal areas (Bange et al., 1994; Rhee et al., 2009).

The concentration of coastal $\mathrm{CH}_{4}\left(\left[\mathrm{CH}_{4}\right]\right)$ and its emission to the atmosphere are regulated by a dynamic balance between its sources and sinks. Sources of $\mathrm{CH}_{4}$ in coastal waters can be roughly divided into in situ processes (within the water column) and ex situ processes (outside of the water column). In situ processes include (1) biological $\mathrm{CH}_{4}$ production (methanogenesis) under anoxic conditions and subsequent release from the fecal pellet microenvironment (Karl and Tilbrook, 1994; Tilbrook and Karl, 1995) and/or, under oxic conditions, through decomposition of methylated precursors, such as methylphosphonates (Karl et al., 2008; Metcalf et al., 2012) and dimethylsulfoniopropionate (DMSP) and/or dimethylsulfoxide (DMSO) (Damm et al., 2008, 2015; Weller et al., 2013; Zindler et al., 2013) and (2) photochemical production from precursors of methyl radical (Bange and Uher, 2005; Zhang and Xie, 2015). Ex situ processes usually refer to (1) $\mathrm{CH}_{4}$ release from the seafloor, including release from sediment due to diagenesis of buried organic matter (Bange et al., 2010; Sun et al., 2018) and release from other natural geological settings such as submarine hydrocarbon seeps (e.g., Boles et al., 2001; Reeburgh, 2007) and (2) $\mathrm{CH}_{4}$ addition from river runoffs, which is significant in estuarine areas (e.g., Ye et al., 2016; Sun et al., 2018). In addition, anthropogenic eutrophication (e.g., Naqvi et al., 2010; Borges et al., 2016) and episodic oil-gas leakages (e.g., Zhang et al., 2014; Zhang and Zhai, 2015) can enhance the $\mathrm{CH}_{4}$ concentration in the overlying water column.

The major sink of dissolved $\mathrm{CH}_{4}$ in seawater is usually consumption in aerobic environments by methanotrophs (Hanson and Hanson, 1996; Reeburgh, 2007; Murrell, 2010). This process is usually characterized by first-order kinetics and is related to local methanotroph communities. The reaction rate can be measured using ${ }^{3} \mathrm{H}-\mathrm{CH}_{4}$ or ${ }^{14} \mathrm{C}-\mathrm{CH}_{4}$ tracer incubations and usually spans from 0.001 to $10 \mathrm{nmol} \mathrm{L}^{-1}$ day $^{-1}$ (Mau et al., 2013). The remaining $\mathrm{CH}_{4}$ that has bypassed the microbial filter escapes into the overlying atmosphere through the sea-air interface.

In addition, water column stratification hampers upward transportation of subsurface $\mathrm{CH}_{4}$, affecting the biogeochemical cycling of $\mathrm{CH}_{4}$ in the Baltic Sea and Black Sea (e.g., Schmale et al., 2010a,b). Also, the DO concentration plays an important role in modulating methanogen and methanotroph activities (e.g., Reeburgh, 2007; Steinle et al., 2017).

The Bohai Sea is a semi-enclosed shallow-water marginal sea of the northwest Pacific Ocean with seasonal stratification (Huang et al., 1999; Zhao et al., 2017; Zhou et al., 2017) and a summertime dissolved oxygen (DO) deficit in its bottom waters (Zhai et al., 2012, 2019; Zhao et al., 2017; Wei et al., 2019). Spatiotemporal variations in $\left[\mathrm{CH}_{4}\right]$ and thereby sea-to-air $\mathrm{CH}_{4}$ fluxes have been previously investigated by Li et al. (2010), Zhang et al. (2014), and Zang (2018), showing that the Bohai Sea is usually supersaturated with $\mathrm{CH}_{4}$, with moderate sea-to-air $\mathrm{CH}_{4}$ fluxes from 0.8 to $53.9 \mu \mathrm{mol} \mathrm{m} \mathrm{m}^{-2} \mathrm{~d}^{-1}$. However, so far, there have been no studies relating the sea-to-air $\mathrm{CH}_{4}$ flux to multiple sources in this area, although several earlier studies showed that river discharges and oil-gas leakages contributed to the Bohai Sea $\mathrm{CH}_{4}$ release (Gu et al., 2011; Zhang et al., 2014).

In this study, we investigated the spatial distribution of $\mathrm{CH}_{4}$ and sea-to-air $\mathrm{CH}_{4}$ flux in the central Bohai Sea in summer 2018, examined various $\mathrm{CH}_{4}$ sources from the seafloor via the relationship between $\mathrm{CH}_{4}$ and $\mathrm{DO}$, measured net $\mathrm{CH}_{4}$ cycling rates at selected sampling sites, and estimated the flux of seafloor $\mathrm{CH}_{4}$ release based on a steady-state box model. Through this study, we attempted to better understand $\mathrm{CH}_{4}$ dynamics in the Bohai Sea by interpreting $\mathrm{CH}_{4}$ source and sink processes under the modulation of summertime stratification. The research design may benefit other biogeochemical research into coastal $\mathrm{CH}_{4}$ cycling with similar oceanic settings.

\section{MATERIALS AND METHODS}

\section{Study Area}

The Bohai Sea covers an area of $77284 \mathrm{~km}^{2}$, with an average depth of $18.7 \mathrm{~m}$; the area with a depth of $<30 \mathrm{~m}$ constitutes $95 \%$ of the total area of the sea (Figure 1). It opens to the North Yellow Sea through the Bohai Strait. In summer, seawater from the North Yellow Sea enters the Bohai Sea through the northern strait, moves anticlockwise around the central basin, and finally flows out through the southern strait (Guan, 1994; Huang et al., 1999), involving riverine water discharges from the Yellow River and the Luanhe River (Figure 1). The hydraulic residence time of the entire Bohai Sea is estimated to be 1.6 years (Li et al., 2015).

Sandy sediments dominate the eastern Bohai Sea, whereas clayey sediments are mainly found in the middle and eastern parts (Liu et al., 1998; Zhu and Chang, 2000). However, the Laotieshan Channel, which is located in the northern part of the Bohai Strait and has a maximum depth of $86 \mathrm{~m}$, has neither Holocene sediments nor Late Pleistocene sediments due to strong tidal erosion (up to $250 \mathrm{~cm} \mathrm{~s}^{-1}$ ) (Liu et al., 1998). In addition, the Bohai Sea is the largest offshore crude oil/gas development base in China, where hydrocarbon-related overpressure commonly occurs in the Paleogene strata (Xu et al., 2018) and oil/gas leakages have been previously observed (Zhang et al., 2014).

\section{Sampling}

Thirty-five grid stations were sampled to obtain an overview of the central Bohai Sea (Figure 1), spanning the historically 


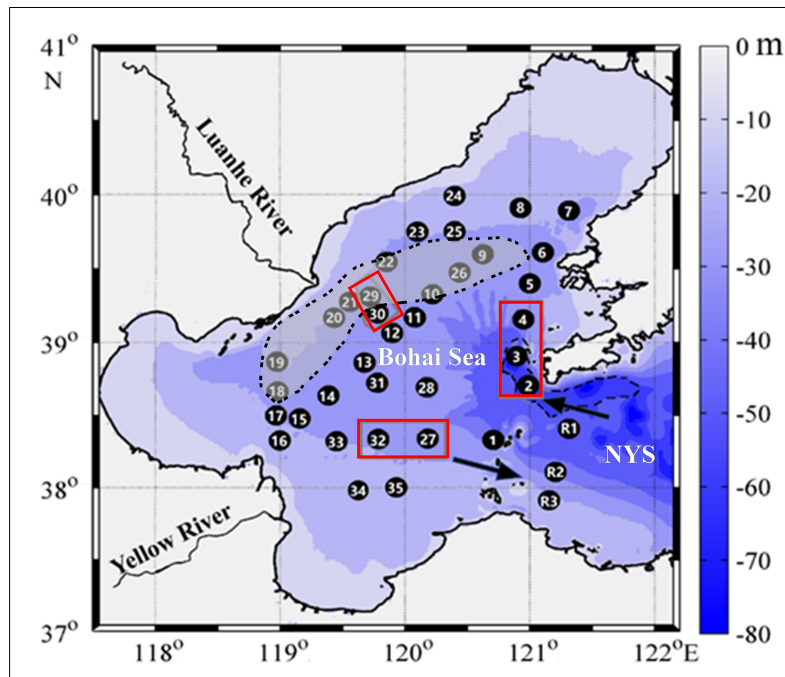

FIGURE 1 | Sampling sites in the Bohai Sea and the North Yellow Sea (NYS). The deep Laotieshan Channel is circled by a dashed line. The Bohai Sea inflow current and Bohai Sea outflow current are indicated by arrows. Stations 2, 3, and 4 are located in the Laotieshan Channel. Stations 27 and 32 are located near active oil/gas platforms (Zhang et al., 2014). Incubation experiments were carried out at stations 29 and 30, in or near a bottom-water oxygen-depletion region (the gray shadowed area circled by a dotted line) observed in late August 2011 by Zhai et al. (2012).

summertime oxygen-depleted area, the Laotieshan Channel, and the oil/gas exploration area. Additionally, three reference stations (stations R1, R2, and R3) located in the adjacent North Yellow Sea were also included. Sample collection was conducted onboard $R / V$ Haili in late summer (22-31 August) 2018. Bulk water samples of different depths were collected during upcasts using 10 L Niskin bottles mounted on a Rosette ${ }^{\mathrm{TM}}$ sampler (model 1018, General Oceanics, United States). According to the Joint Global Ocean Flux Study (JGOFS) protocols (Knap et al., 1996), discrete water samples were taken in sequence from $\mathrm{CH}_{4}$ and DO to dissolved inorganic carbon (DIC) and total alkalinity (TAlk) at three to nine depths, including the near-surface water layer ( $\sim 3 \mathrm{~m}$ below the free surface) and the near-bottom water layer ( $\sim 2 \mathrm{~m}$ above the seafloor).

\section{Analyses}

$\left[\mathrm{CH}_{4}\right]$ in seawater was measured onboard immediately after sampling at a rate of 6-8 samples per hour. A static headspace method was adopted (Zhang and Xie, 2015). Briefly, water samples were transferred to a $50-\mathrm{mL}$ glass syringe fitted with three-way valves (glass fiber reinforced polypropylene, GFPP). They were rinsed with water samples before the final drawing, including at least one bubble-free flushing. Then $5 \mathrm{~mL} \mathrm{CH}_{4}$ free $\mathrm{N}_{2}$ was introduced into the syringe to obtain a 1:6 gas:water ratio. The syringe was vigorously shaken for $6 \mathrm{~min}$, and the equilibrated headspace gas was injected into a Peak Performer 1 FID gas chromatograph (1-mL sample loop; Peak laboratories, United States) for $\mathrm{CH}_{4}$ quantification. The analyzer was standardized by frequent injections of a gaseous $\mathrm{CH}_{4}$ standard of 5.00 parts per million by volume (ppmv) (balanced with pure $\mathrm{N}_{2}$; National Institute of Metrology, China). This single-point calibration protocol was adopted since the analyzer consistently responded linearly up to $20.1 \mathrm{ppmv}$. In keeping with the $100 \%$ relative humidity of the samples, the dry $\mathrm{CH}_{4}$ standard was saturated with water vapor before injection. To estimate the analytical blank, a water sample was repeatedly extracted with pure $\mathrm{N}_{2}$ until its $\mathrm{CH}_{4}$ signal diminished to a stable level. Ten subsequent analyses of the extracted sample arrived at a mean blank of $0.007 \mathrm{nmol} \mathrm{\textrm {kg } ^ { - 1 }}$ with a standard deviation of $0.002 \mathrm{nmol} \mathrm{kg}^{-1}$. The lower detection limit, defined as three times the standard deviation, was thus $0.006 \mathrm{nmol} \mathrm{kg}{ }^{-1}$. The analytical reproducibility was determined to be $\pm 4 \%(n=10)$ at a $\left[\mathrm{CH}_{4}\right]$ of $\sim 5 \mathrm{nmol} \mathrm{kg}^{-1}$. Air samples were drawn at the bow, facing the wind, into $10-\mathrm{mL}$ glass syringes and injected into the $\mathrm{CH}_{4}$ analyzer within minutes to measure the atmospheric $\mathrm{CH}_{4}$ partial pressure.

Seawater temperature and salinity were measured with CTD probes (OCEAN SEVEN 304Plus, Italy). DO was measured onboard using the Winkler titration method. The DO saturation (DO\%) was calculated as the field-measured DO concentration divided by the DO concentration at equilibrium with the atmosphere, as per the Benson and Krause (1984) equation and the field-measured sea surface barometric pressure. To quantify the effects of net community metabolism, apparent oxygen utilization (AOU) was calculated by subtracting the field-measured DO concentration from the air-equilibrated DO. Assuming that the water starts in a fully saturated state and ignoring the effects of immediate air-sea DO exchange and water mixing, an $\mathrm{AOU}>0$ implies net community respiration, while an $\mathrm{AOU}<0$ indicates net community production.

\section{$\mathrm{CH}_{4}$ Saturation and Sea-Air Flux Calculations}

The saturation ratios (SR) of $\mathrm{CH}_{4}$ were calculated as:

$$
\mathrm{SR}(\%)=\left[\mathrm{CH}_{4}\right] /\left[\mathrm{CH}_{4}\right]_{\mathrm{eq}} \times 100
$$

where $\left[\mathrm{CH}_{4}\right]_{\mathrm{eq}}$ is the surface water $\mathrm{CH}_{4}$ concentration in equilibrium with the atmosphere. This was calculated using the measured atmospheric partial pressure of $\mathrm{CH}_{4}$ and Henry's Law constants (Wiesenburg and Guinasso, 1979).

$\mathrm{CH}_{4}$ flux across the sea-air interface was estimated using the stagnant laminar layer model of Liss and Slater (1974), which expresses the flux as a product of gas transfer velocity $(k)$ and the difference between measured surface water $\left[\mathrm{CH}_{4}\right]$ and $\left[\mathrm{CH}_{4}\right]_{\text {eq }}$, i.e.,

$$
F=k \times\left(\left[\mathrm{CH}_{4}\right]-\left[\mathrm{CH}_{4}\right]_{\mathrm{eq}}\right)
$$

where $k$ was calculated from the empirical equation of Wanninkhof (2014). Wind speeds were recorded at a 10-m height using a shipboard automatic weather station, and the average was used to calculate $k$ at each station.

\section{Measurement of $\mathrm{Net}^{\mathrm{CH}_{4}}$ Cycling Rates}

Shipboard incubations were carried out to estimate net $\mathrm{CH}_{4}$ cycling rates within the water column of stations 29 and 30 . Briefly, unfiltered surface or bottom waters were drawn from 

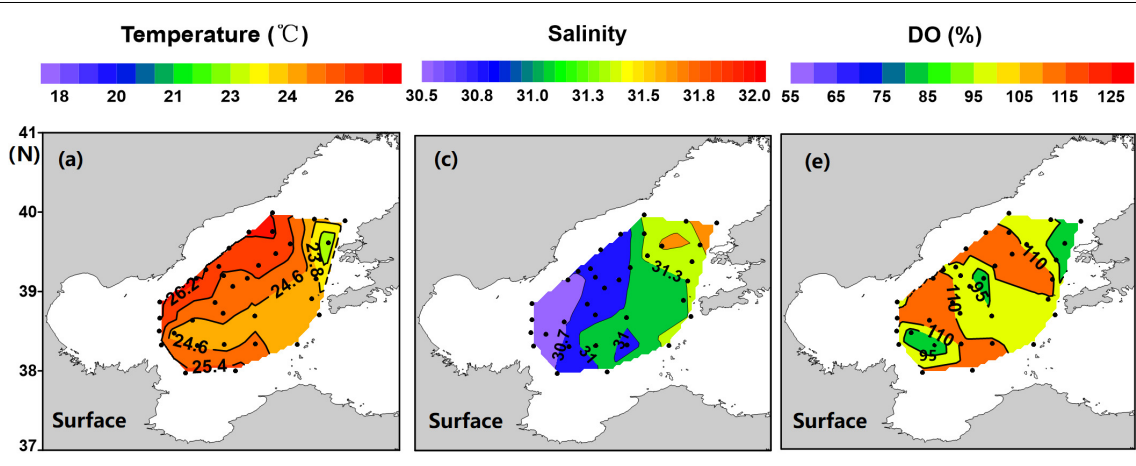

$\mathrm{CH}_{4}(\mathrm{nmol} \mathrm{kg-1)}$
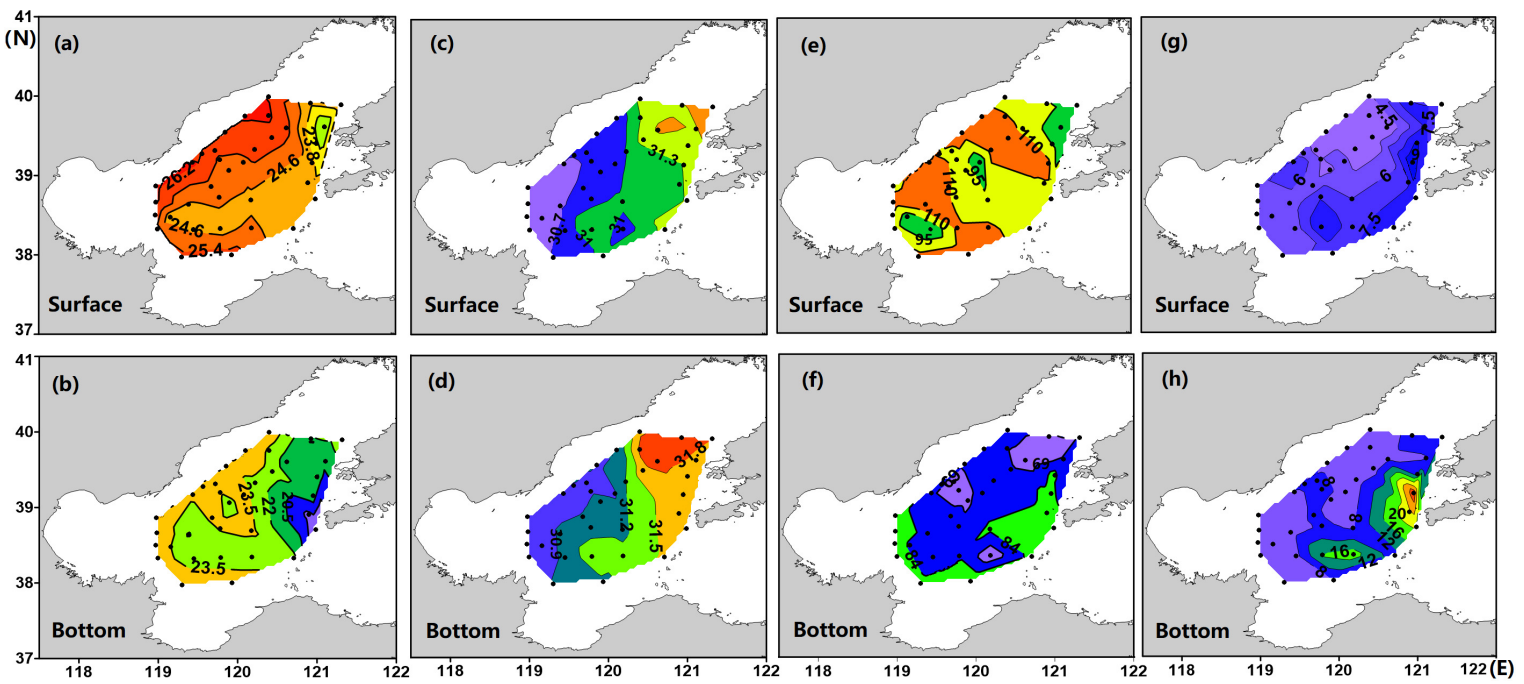

FIGURE 2 | Sea surface and bottom-water distributions of temperature $\mathbf{( a , b )}$, salinity $\mathbf{( c , d ) , ~ D O ~ s a t u r a t i o n ~}(\mathbf{e}, \mathbf{f})$, and [CH 4$](\mathbf{g}, \mathbf{h})$ in the central Bohai Sea in summer 2018.

the samplers directly into 50-mL glass syringes (with a threeway GFPP valve). The syringes were rinsed with sample water three times, including at least one bubble-free flushing before the final drawing, and then incubated in the dark at in situ temperature $\pm 2{ }^{\circ} \mathrm{C}$. They were analyzed sequentially for $\left[\mathrm{CH}_{4}\right]$ at intervals of $6-10 \mathrm{~h}$. To keep the water sample (and the enclosed microbial community) close to its original state, incubation lasted only for up to $16.2 \mathrm{~h}$ at station 29 and $33.7 \mathrm{~h}$ at station 30. Data were plotted as a time series. Net $\mathrm{CH}_{4}$ cycling rates were estimated from the initial slope of the decrease of $\left[\mathrm{CH}_{4}\right]$ over time.

\section{Potential Energy Anomaly}

To indicate the degree of stratification in the water column, we calculated the potential energy anomaly $(\varphi)$ following Simpson (1981), i.e.,

$$
\begin{gathered}
\varphi=\frac{1}{h} \int_{-h}^{0}(\bar{\rho}-\rho) g z d z \\
\bar{\rho}=\frac{1}{h} \int_{-h}^{0} \rho d z
\end{gathered}
$$

where $h$ indicates the water depth (m), $\rho$ is the seawater density $\left(\mathrm{kg} \mathrm{m}^{-3}\right), g$ is the gravitational acceleration $\left(\mathrm{m} \mathrm{s}^{-2}\right)$, and $z$ is the depth interval (m). $\varphi$ is the amount of work per unit volume required to complete vertical mixing of the water mass.

\section{RESULTS}

\section{Hydrological and Metabolic Settings}

The water column at each station was vertically separated into two layers by the thermocline, with the temperature ranging from
22.1 to $26.4^{\circ} \mathrm{C}$ in the surface layer and from 17.4 to $25.6^{\circ} \mathrm{C}$ in the bottom layer (Figures 2a,b). The lowest temperature was found at the bottom water of Laotieshan Channel, where cold bottom water of the North Yellow Sea enters the Bohai Sea (Figures 2a,b). Salinity in general was vertically homogenous and horizontally varied within a narrow range, ranging from 30.4 to 31.7 in the surface layer and from 30.6 to 32.0 in the bottom layer (Figures 2c,d). Since the central Bohai Sea is far away from river plumes, no horizontal gradients of temperature and/or salinity were observed.

DO\% decreased from $105.9 \pm 11.9 \%$ (range $81.1-124.5 \%$ ) in the surface layer to $77.5 \pm 12.0 \%$ (range 54.9-97.0\%) in the bottom layer (Figures 2e,f). Three DO-deficit patches were identified in the bottom layer, i.e., stations 8 and 9 with DO\% of $56.8 \%$ and $57.9 \%$, station 27 with DO\% of $57.4 \%$, and stations 29 and 30 with DO\% of $57.9 \%$ and $54.9 \%$, respectively (Figure 2f).

It is worth noting that DO\% was negatively related to $\mathrm{CO}_{2}$ fugacity $\left(f \mathrm{CO}_{2}\right)$ and that $\mathrm{AOU}$ was positively related to oversaturated DIC (Figure A1). Therefore, metabolic processes (including primary production in the surface layer and community respiration in the bottom layer) played a dominant role in regulating biogeochemical settings within the survey area.

\section{Distribution of $\mathrm{CH}_{4}$ and Sea-to-Air Flux}

The atmospheric $\mathrm{CH}_{4}$ mixing ratio $\left(\mathrm{m}_{\mathrm{atm}}\right)$ ranged from 1.83 to $2.07 \mathrm{ppmv}$ during this cruise, with an average of $1.89 \pm 0.05 \mathrm{ppmv}$ (Table 1). Wind speeds during the survey were averaged at $5.0 \pm 2.0 \mathrm{~m} \mathrm{~s}^{-1}$ (ranging between 2.0 and $9.1 \mathrm{~m} \mathrm{~s}^{-1}$ ).

Seawater $\left[\mathrm{CH}_{4}\right]$ increased from $5.8 \pm 2.0 \mathrm{nmol} \mathrm{kg}^{-1}$ (ranging between 3.1 and $10.3 \mathrm{nmol} \mathrm{kg}^{-1}$ ) in the surface layer (Figure 2 $\mathbf{g}$ ) to $8.9 \pm 5.4 \mathrm{nmol} \mathrm{kg}^{-1}$ (ranging between 4.2 and $31.1 \mathrm{nmol}$ $\mathrm{kg}^{-1}$ ) in the bottom layer (Figure $2 \mathbf{h}$ ). Two patches with peak 

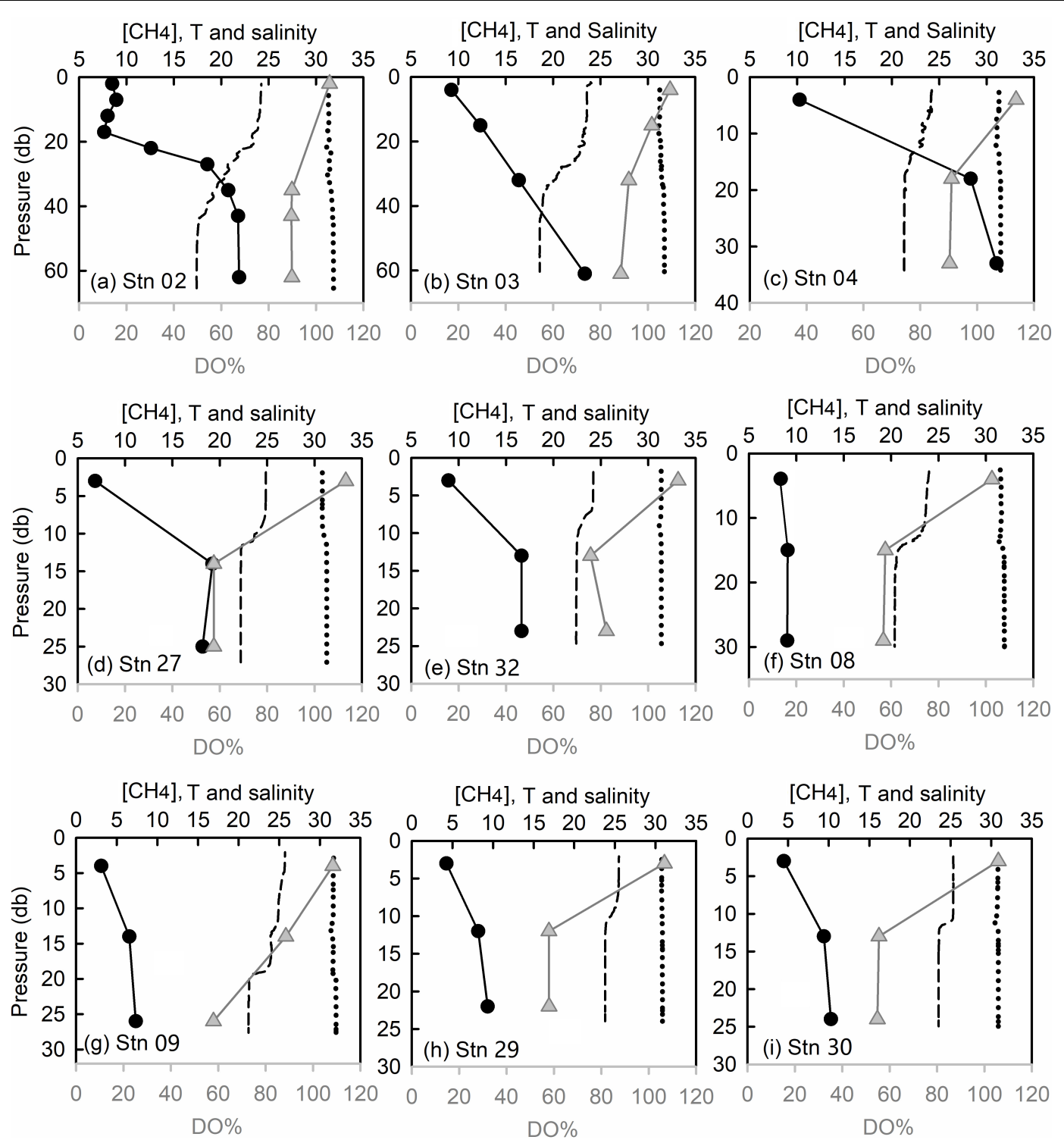

FIGURE 3 | Profiles of $\left[\mathrm{CH}_{4}\right]$ (nmol kg-1, filled circles in black), DO\% (filled triangles in gray), temperature $\left({ }^{\circ} \mathrm{C}\right.$, dashed lines), and salinity (dotted lines) in the Laotieshan Channel $(\mathbf{a}-\mathbf{c})$, the oil/gas spill areas $(\mathbf{d}-\mathbf{e})$, and the DO deficit areas $(\mathbf{f}-\mathbf{i})$.

$\left[\mathrm{CH}_{4}\right]$ values were identified. One was observed in the bottom waters of the deep Laotieshan Channel (stations 02, 03, and $04)$, where the $\left[\mathrm{CH}_{4}\right]$ values were $21.8,23.4$, and $31.0 \mathrm{nmol}$ $\mathrm{kg}^{-1}$, respectively (Figures 3a-c). The other was located in the bottom waters of the oil/gas development area at stations 27 and 32 , where the $\left[\mathrm{CH}_{4}\right]$ values were 19.2 and $16.6 \mathrm{nmol} \mathrm{kg}^{-1}$, respectively (Figures 3d,e).

Correspondingly, SR increased from $281 \pm 99 \%$ (ranging between 150 and 500\%) in the surface layer to $433 \pm 261 \%$ (ranging between 207 and 1441\%) in the bottom layer. The highest SR value, $1441 \%$, was observed in the bottom water of station 04, where DO\% was measured at quite a high level of $\sim 90 \%$. The lowest SR value, $150 \%$, was observed in the surface layer of station 09. All of them indicated that $\mathrm{CH}_{4}$ was supersaturated with respect to the atmospheric equilibrium throughout the water column in our surveyed area. The sea-toair flux was estimated to be $6.5 \pm 3.4 \mu \mathrm{mol} \mathrm{m}{ }^{-2} \mathrm{~d}^{-1}$ (ranging from 1.8 to $13.5 \mu \mathrm{mol} \mathrm{m}{ }^{-2} \mathrm{~d}^{-1}$ ) (Table 1 ), showing again that the Bohai Sea served as a source of atmospheric $\mathrm{CH}_{4}$.

\section{Net $\mathrm{CH}_{4}$ Cycling Rates}

During incubation at stations 29 and $30,\left[\mathrm{CH}_{4}\right]$ in surface waters remained nearly stable, while $\left[\mathrm{CH}_{4}\right]$ in bottom waters decreased exponentially with prolonged incubation time (Figure 4). Although the bottom-water incubation at station 29 stopped after $9.95 \mathrm{~h}$ due to accidental water sample loss, the two initial data points showed a similar trend to that of station 30. Based on the initial decrease rate of $\left[\mathrm{CH}_{4}\right]$ over the incubation time, 
TABLE 1 | Locations of sampling stations with water depth, sea surface temperature (SST), salinity, atmospheric $\mathrm{CH}_{4}$ mixing ratio $\left(\mathrm{m}_{\text {atm }}\right)$, [ $\left.\mathrm{CH} \mathrm{H}_{4}\right]$, air-sea exchange velocity $(k)$, and sea-air flux.

\begin{tabular}{|c|c|c|c|c|c|c|c|c|c|}
\hline Stn & $\begin{array}{l}\text { Long. } \\
\left.\text { ( }{ }^{\circ} \mathrm{E}\right)\end{array}$ & $\begin{array}{l}\text { Lat. } \\
\left({ }^{\circ} \mathbf{N}\right)\end{array}$ & $\begin{array}{l}\text { Depth } \\
\text { (m) }\end{array}$ & $\begin{array}{l}\text { SST } \\
\left({ }^{\circ} \mathrm{C}\right)\end{array}$ & Salinity & $\begin{array}{l}\mathrm{m}_{\mathrm{atm}} \\
\mathrm{ppmv}\end{array}$ & $\begin{array}{c}{\left[\mathrm{CH}_{4}\right]} \\
\left(\mathrm{nmol} \mathrm{kg}^{-1}\right)\end{array}$ & $\begin{array}{c}k \\
\left(\mathrm{~cm} \mathrm{~h} \mathrm{~h}^{-1}\right)\end{array}$ & 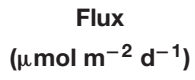 \\
\hline 1 & 120.71 & 38.33 & 28.0 & 23.76 & 31.38 & 1.93 & 8.71 & 6.66 & 10.85 \\
\hline 2 & 120.99 & 38.70 & 65.0 & 24.22 & 31.31 & / & 8.49 & 6.73 & 10.62 \\
\hline 3 & 120.89 & 38.91 & 60.9 & 23.58 & 31.26 & / & 7.27 & 6.63 & 11.87 \\
\hline 4 & 120.95 & 39.16 & 36.0 & 24.13 & 31.30 & / & 10.27 & 6.72 & 13.52 \\
\hline 5 & 121.00 & 39.40 & 27.0 & 23.08 & 31.44 & / & 9.38 & 6.55 & 11.72 \\
\hline 6 & 121.11 & 39.61 & 37.0 & 22.11 & 31.59 & / & 7.62 & 6.40 & 8.63 \\
\hline 7 & 121.31 & 39.89 & 29.0 & 24.21 & 31.77 & / & 6.44 & 6.73 & 7.26 \\
\hline 8 & 120.93 & 39.91 & 30.5 & 23.94 & 31.57 & 1.90 & 9.03 & 6.68 & 11.43 \\
\hline 9 & 120.62 & 39.60 & 29.0 & 25.65 & 31.64 & 1.83 & 3.08 & 6.96 & 1.82 \\
\hline 10 & 120.22 & 39.33 & 24.3 & 25.83 & 31.00 & 1.85 & 3.18 & 6.99 & 1.93 \\
\hline 11 & 120.08 & 39.17 & 21.8 & 25.16 & 30.64 & 1.86 & 5.07 & 6.89 & 5.17 \\
\hline 12 & 119.90 & 39.06 & 22.8 & 25.41 & 30.72 & 1.97 & 4.23 & 6.93 & 3.76 \\
\hline 13 & 119.68 & 38.86 & 24.5 & 25.15 & 30.81 & 1.98 & 4.67 & 6.89 & 4.45 \\
\hline 14 & 119.39 & 38.64 & 25.5 & 24.51 & 30.66 & 1.84 & 5.06 & 6.78 & 4.95 \\
\hline 15 & 119.16 & 38.48 & 23.0 & 24.10 & 30.55 & 1.90 & 5.60 & 6.72 & 5.80 \\
\hline 16 & 119.00 & 38.33 & 20.7 & 25.26 & 30.53 & 1.88 & 5.54 & 6.91 & 5.91 \\
\hline 17 & 118.97 & 38.50 & 23.5 & 26.00 & 30.57 & 1.87 & 5.22 & 7.03 & 5.58 \\
\hline 18 & 118.98 & 38.66 & 24.3 & 26.36 & 30.49 & 1.91 & 3.55 & 7.09 & 2.68 \\
\hline 19 & 118.98 & 38.87 & 25.2 & 26.40 & 30.58 & 1.88 & 5.35 & 7.09 & 5.85 \\
\hline 20 & 119.43 & 39.17 & 21.5 & 26.43 & 30.45 & 1.89 & 7.98 & 7.10 & 10.38 \\
\hline 21 & 119.56 & 39.28 & 22.0 & 25.71 & 30.76 & 1.84 & 4.95 & 6.98 & 4.97 \\
\hline 22 & 119.85 & 39.55 & 23.2 & 26.00 & 30.86 & 1.83 & 3.75 & 7.02 & 3.15 \\
\hline 23 & 120.10 & 39.75 & 24.0 & 26.27 & 30.75 & 1.87 & 3.71 & 7.07 & 3.03 \\
\hline 24 & 120.40 & 39.99 & 21.5 & 26.20 & 31.38 & 1.86 & 4.11 & 7.05 & 3.73 \\
\hline 25 & 120.40 & 39.75 & 28.2 & 26.30 & 31.29 & 1.85 & 3.64 & 7.07 & 2.96 \\
\hline 26 & 120.44 & 39.48 & 25.4 & 25.90 & 31.44 & 1.89 & 3.36 & 7.00 & 2.33 \\
\hline 27 & 120.18 & 38.34 & 27.3 & 24.85 & 30.81 & 1.83 & 6.84 & 6.84 & 7.99 \\
\hline 28 & 120.18 & 38.69 & 26.3 & 24.29 & 31.11 & 1.86 & 6.02 & 6.74 & 6.56 \\
\hline 29 & 119.72 & 39.31 & 24.5 & 25.47 & 30.76 & 1.85 & 4.24 & 6.94 & 3.70 \\
\hline 30 & 119.78 & 39.20 & 25.5 & 25.32 & 30.83 & 1.86 & 4.47 & 6.91 & 4.22 \\
\hline 31 & 119.78 & 38.72 & 26.3 & 24.81 & 30.85 & 1.86 & 7.39 & 6.83 & 9.12 \\
\hline 32 & 119.79 & 38.34 & 25.0 & 24.21 & 31.39 & 1.91 & 8.92 & 6.73 & 11.47 \\
\hline 33 & 119.45 & 38.32 & 22.5 & 24.45 & 30.76 & 2.07 & 5.23 & 6.77 & 5.35 \\
\hline 34 & 119.30 & 37.98 & 18.5 & 25.60 & 30.72 & 1.92 & 5.30 & 6.96 & 5.64 \\
\hline 35 & 119.93 & 38.00 & 18.0 & 25.70 & 31.07 & 1.93 & 6.59 & 6.97 & 7.59 \\
\hline
\end{tabular}

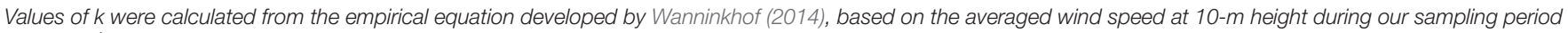
$\left(5.0 \mathrm{~m} \mathrm{~s}^{-1}\right)$.

the net loss rates of $\mathrm{CH}_{4}$ in the bottom waters were calculated to be $0.124 \mathrm{nmol} \mathrm{kg}^{-1} \mathrm{~h}^{-1}$ at station 29 and $0.153 \mathrm{nmol}$ $\mathrm{kg}^{-1} \mathrm{~h}^{-1}$ at station 30 .

\section{DISCUSSION}

\section{Comparisons With Results in the Literature}

In this study, DO was relatively abundant as compared to our previous reports (Zhai et al., 2012, 2019; Zhao et al., 2017), likely due to disturbance by typhoons. During 2-30 days prior to our field survey, three typhoon events (named Ampil, Yagi, and Rumbia, respectively ${ }^{1}$ ) affected the Bohai Sea. It is expected that the sea gales weakened the stratification in the Bohai Sea, leading to basin-wide bottom water ventilation. A similar result was observed in August 2012 in the Bohai Sea (Zhai et al., 2019). However, the locations of DO-deficit areas detected in this study were similar to the DO-deficient zones previously outlined by Zhao et al. (2017) and Wei et al. (2019).

The atmospheric $\mathrm{CH}_{4}$ mixing ratio in this study $(1.89 \pm 0.05 \mathrm{ppmv})$ is much lower than in our previous

\footnotetext{
${ }^{1}$ http://agora.ex.nii.ac.jp/digital-typhoon/
} 


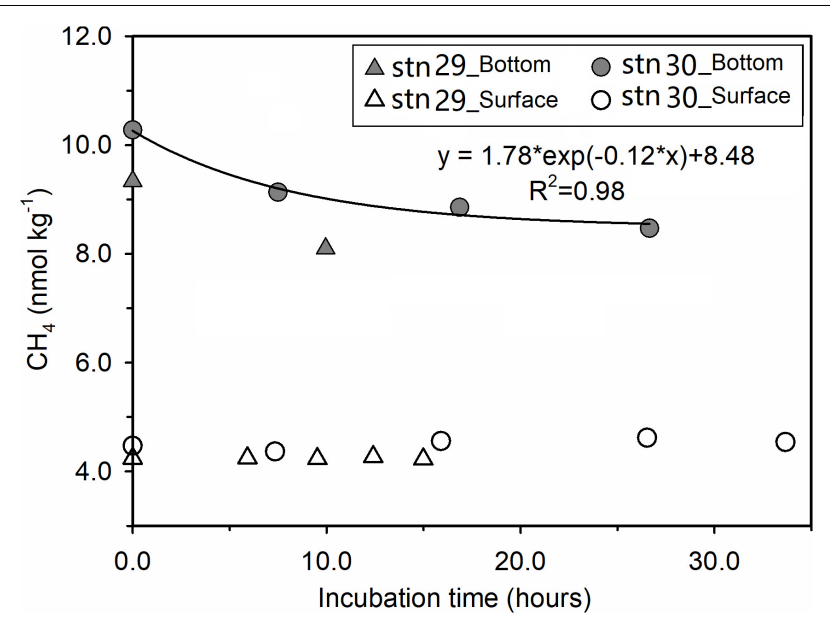

FIGURE 4 | Evolution of $\left[\mathrm{CH}_{4}\right]$ during our field incubation experiments. Filled and open triangles stand for bottom waters and surface waters collected from station 29, while filled and open circles are for those from station 30. The solid line is the best fit of data for the bottom water from station 30.

results from measurements in the central Bohai Sea in July 2012 (2.07 ppmv, Zhang et al., 2014), probably also due to the dilution effect of the three typhoons, which originated from the adjacent open ocean, i.e., the western North Pacific Ocean. However, this field-measured result is slightly higher than the globally averaged marine surface mean value for August 2018 (1.85 $\mathrm{ppmv}^{2}$ ).

Our sea surface SR\% values $(285 \pm 99 \%)$ are comparable with previous results, i.e., $288 \pm 99 \%$ in August 2008 (Li et al., 2010) and $219 \pm 67 \%$ in August 2012 (Zhang et al., 2014). The sea-toair flux estimated in this study falls between the previous results of $8.1 \pm 4.2 \mu \mathrm{mol} \mathrm{m}^{-2} \mathrm{~d}^{-1}$ (Li et al., 2010) and $2.8 \pm 2.5 \mu \mathrm{mol}$ $\mathrm{m}^{-2} \mathrm{~d}^{-1}$ (Zhang et al., 2014) observed in this region, but is much lower than the global average value for continental shelves ( $\sim 30 \mu \mathrm{mol} \mathrm{m}^{-2} \mathrm{~d}^{-1}$, Borges et al., 2016).

\section{Three Types of $\mathrm{CH}_{4}$ Sources From the Seafloor}

The elevation in $\left[\mathrm{CH}_{4}\right]$ with increasing depth indicated that the seafloor released $\mathrm{CH}_{4}$ into the water column. Three types of $\mathrm{CH}_{4}$ sources were identified from the plot of SR vs. DO\% (Figure 5A).

\section{Type I: $\mathrm{CH}_{\mathbf{4}}$ Production From Biogenic Process}

The linearly negative correlation between SR and DO\% $(\mathrm{SR}=-2.70 \times \mathrm{DO} \%+559.87, r=-0.507, n=89, p<0.01$, excluding bottom waters at stations 02, 03, 04, 27, and 32 in Figure 5A) indicates that $\mathrm{CH}_{4}$ production at most stations was favored under DO-deficient conditions. Bottom-water DO in the Bohai Sea is likely regulated by remineralization of sedimentary organic matter (Zhao et al., 2017; Wei et al., 2019; Figure A1). Various methanogens (including Methanococcoides, Methanolobus, and Methanosarcina) have been identified in the sediments of the Bohai Sea, and thus the Bohai Sea may have great potential for methane productivity (Wang et al., 2019).

${ }^{2}$ https://www.esrl.noaa.gov/gmd
The $\mathrm{CH}_{4}$ at these stations was therefore likely produced from the decay of earlier buried organic matter and consequent sedimentary release.

Our $\left[\mathrm{CH}_{4}\right]$ results in DO-deficient $(\mathrm{DO} \%<60 \%)$ bottom waters of the Bohai Sea $\left(7.3-10.3 \mathrm{nmol} \mathrm{kg}^{-1}\right.$, Figures $\left.3 \mathbf{f}-\mathbf{i}\right)$ were lower than those in hypoxic waters within the East China Sea (up to $31 \mathrm{nmol} \mathrm{L}^{-1}$, Ye et al., 2016) and much lower than many anoxic zones, e.g., up to $104 \mathrm{nmol} \mathrm{L}^{-1}$ in the shelf water of the west coast of India (Shirodkar et al., 2018) and up to $1086 \mathrm{nmol} \mathrm{L}^{-1}$ in the bottom Baltic Sea (Schmale et al., 2010b). This comparison also indicates a potential relationship between high $\left[\mathrm{CH}_{4}\right]$ and low DO levels in the water column. A similar negative correlation has been found at a patch of hypoxic area in the East China Sea (Ye et al., 2016), where higher $\left[\mathrm{CH}_{4}\right]$ and a lower DO level lead to a more negative slope between SR and $\mathrm{DO} \%(\mathrm{SR}=-11.34 \times \mathrm{DO} \%+753, r=0.755)$. Thus, the slope of SR vs. DO\% may indicate the relative intensity of biological $\mathrm{CH}_{4}$ production in the sediment and subsequent $\mathrm{CH}_{4}$ release to the bottom water.

\section{Type II: Natural Seeps at the Deep Laotieshan Channel}

During our survey, the highest SR of up to $1441 \%$ were observed in the bottom waters of stations 02, 03, and 04 (Figure 5A), where a high level of bottom-water $\left[\mathrm{CH}_{4}\right]$ was also reported by Li et al. (2010) and Zang (2018) in their summertime surveys. The corresponding DO\% was supersaturated in the surface layer and as high as $89.6 \%, 88.6 \%$, and $90.3 \%$ in the bottom layers of the three stations, respectively. Since an in situ biogenic process is not favored by the high DO level, ex situ $\mathrm{CH}_{4}$ sources must exist. These ex situ sources are neither related to terrestrial input, since salinity was nearly uniform in the whole water column (Figures $3 \mathbf{a}-\mathbf{c}$ ), nor to lateral transportation from the adjacent North Yellow Sea since, the peak values of $\left[\mathrm{CH}_{4}\right]$ at reference

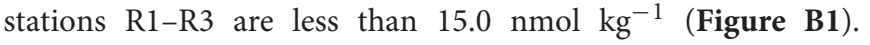
The erosional character of the seabed means that it cannot host methanogenic processes due to an absence of sedimentary organic carbon. Therefore, the high $\left[\mathrm{CH}_{4}\right]$ values in the water column were probably contributed to natural release of $\mathrm{CH}_{4}$ due to fault activities related to hydrocarbon-generation sag (Xu et al., 2018).

Seeps injected large amounts of dissolved $\mathrm{CH}_{4}$ into the bottom waters with few impacts on the DO level. The reason for this may lie in the high inflow rate in the narrow northern Laotieshan Channel (up to $250 \mathrm{~cm} \mathrm{~s}^{-1}$, Liu et al., 1998), which leaves quite a short time for any potential DO-consuming process to take effect. Beside DO, the salinity and temperature in the Laotieshan Channel were also similar to those at reference station R1 (Figure B1), which exhibited representative hydrological settings in the North Yellow Sea.

Type III: $\mathrm{CH}_{4}$ Leakage From Oil/Gas Exploration Area The cluster with the second-highest $\left[\mathrm{CH}_{4}\right]$ values, $19.2 \mathrm{nmol}$ $\mathrm{kg}^{-1}$ and $16.6 \mathrm{nmol} \mathrm{kg}^{-1}$, were observed in the bottom waters at stations 27 and 32, respectively. The corresponding SR values were recorded as $895 \%$ and $823 \%$, respectively (Figure 5A). The two stations were located near active marine 

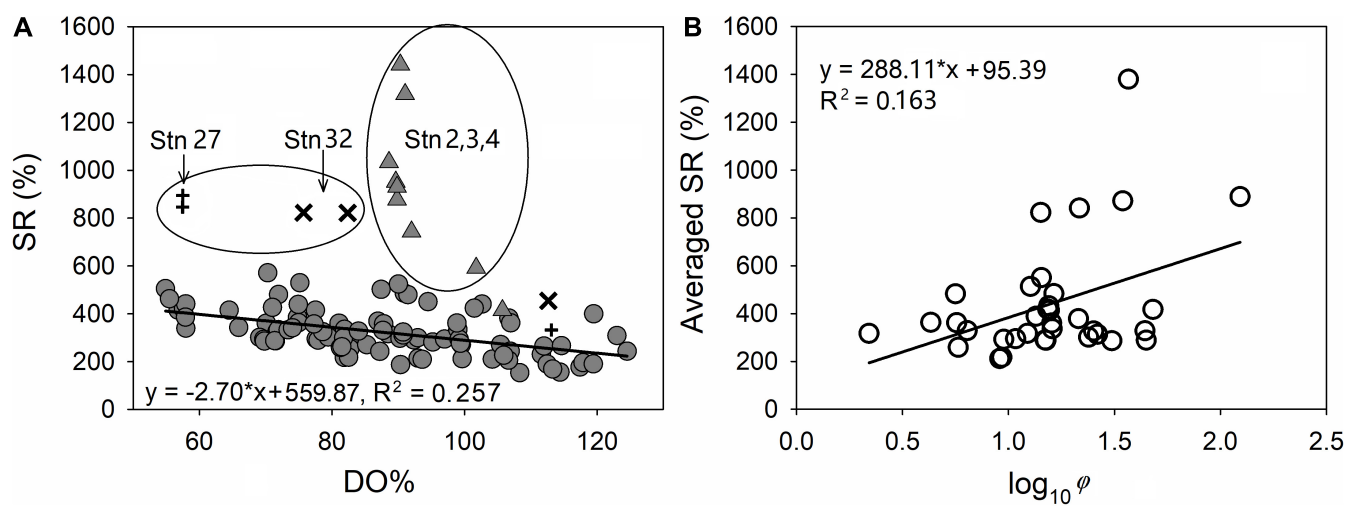

FIGURE 5 | Plots of the saturation ratio of $\mathrm{CH}_{4}$ (SR) versus DO\% at all sampling layers (A) and SR in the bottom layer at each station versus log 10 (showing the degree of stratification in the water column) (B). Triangles in an ellipse are subsurface and bottom-water samples from stations 02 , 03, and 04 , pluses indicate subsurface and bottom-water samples from station 27, crosses indicate subsurface and bottom-water samples from station 32 , and filled circles indicate all water samples from other stations.

oil platforms. Therefore, the high $\mathrm{CH}_{4}$ levels of this cluster were very likely induced by anthropogenic leakages related to the oil/gas exploration, as investigated in our previous studies (Zhang et al., 2014).

In those earlier field studies, the summertime thermocline was broken by strong $\mathrm{CH}_{4}$ leakages, as indicated by high sea surface $\left[\mathrm{CH}_{4}\right]$ of up to $28.7 \mathrm{nmol} \mathrm{kg}{ }^{-1}$ and relatively uniform vertical profiles of temperature and salinity (Zhang et al., 2014). In this study, however, $\mathrm{CH}_{4}$ leakages were likely weaker than before. The upward transportation of dissolved $\mathrm{CH}_{4}$ was blocked by the thermocline, leading to much higher $\left[\mathrm{CH}_{4}\right]$ in the bottom layer than in the surface layer (Figures 3d,e).

In this study, station 27 exhibited stronger stratification than station 32 (with $\varphi$ values of $34.5 \mathrm{~J} \mathrm{~m}^{-3}$ at station 27 and $13.8 \mathrm{~J}$ $\mathrm{m}^{-3}$ at station 32 ), partially explaining why relatively higher $\mathrm{CH}_{4}$ SR (895\%) and lower DO\% (57.4\%) occurred in the bottom layer of station 27, as compared with bottom-water $\mathrm{CH}_{4} \mathrm{SR}$ $(823 \%)$ and DO\% (82.4\%) at station 32 (Figure 5A). Moreover, the weak tidal current in the bottom layer (with a very low flow rate of $0.01-1.48 \mathrm{~cm} \mathrm{~s}^{-1} ; \mathrm{Bi}, 2013$ ) also favored the summertime formation of bottom DO-deficit water at station 27 (Figure 3d).

\section{Biogeochemical Processes of Dissolved $\mathrm{CH}_{4}$ in a Seasonally Stratified Water Column Model Setup and Description}

The amount of dissolved $\mathrm{CH}_{4}$ that flowed out of the Bohai Sea through the south Bohai Strait almost equaled the amount that flowed into the Bohai Sea through the north Bohai Strait, which is indicated by the similar $\left[\mathrm{CH}_{4}\right]$ in the surface layer at the three reference stations, R1-R3 (Figure B1). Since $\mathrm{CH}_{4}$ was not observed to accumulate anticlockwise in the surveyed area (Figures 2g,h), the $\mathrm{CH}_{4}$ emitted from the seafloor is supposed to have been microbially consumed during upward transportation, with any remaining escaping into the overlying atmosphere.

The summertime dynamics of $\mathrm{CH}_{4}$ in a stratified coastal ocean can be illustrated by a two-layer box model (Figure 6).
The variation in depth-integrated $\left[\mathrm{CH}_{4}\right]$ over a certain time period in the surface and bottom layers $\left(\Delta\left[\mathrm{CH}_{4}\right]_{\text {surf }}\right.$ and $\Delta\left[\mathrm{CH}_{4}\right]_{\text {bott }}$, respectively) equals the difference between its sources and sinks, i.e.,

$$
\begin{aligned}
\Delta\left[\mathrm{CH}_{4}\right]_{\text {surf }}= & (\text { Photoproduction })_{\text {surf }}+(\text { Methanogenesis })_{\text {surf }} \\
& -(\text { Methanotrophy })_{\text {surf }}+T-F
\end{aligned}
$$

and

$$
\begin{aligned}
\Delta\left[\mathrm{CH}_{4}\right]_{\mathrm{bott}}= & (\text { Methanogenesis })_{\mathrm{bott}}-(\text { Methanotrophy })_{\mathrm{bott}} \\
& -T+R
\end{aligned}
$$

where the subscript surf stands for the surface layer, bott for the bottom layer, $T$ for upward transport across the thermocline, $F$ for sea-to-air flux, and $R$ for release from the seafloor. The effect of river runoffs is negligible in our surveyed area, as discussed in Section "Hydrological and Metabolic Settings."

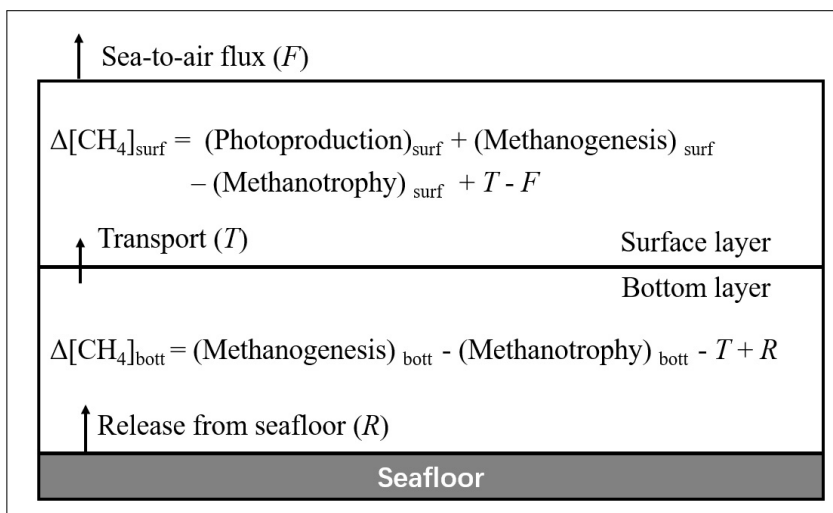

FIGURE 6 | A box model sketching $\mathrm{CH}_{4}$ dynamics in stratified coastal oceans without river plumes (subscript surf stands for the surface layer, bott for the bottom layer, $T$ for upward transport across the thermocline, $F$ for sea-to-air flux, and $R$ for release from the seafloor). 
Photoproduction of $\mathrm{CH}_{4}$, i.e., photomethanification of organic matter, is an abiotic process and has recently been suggested to be a potential source of $\mathrm{CH}_{4}$ in natural waters. Tilbrook and Karl (1995) argued for this source when they observed $\mathrm{CH}_{4}$ formation from sinking particles that were collected using a sediment trap and exposed to direct sunlight. Bange and Uher (2005) assessed the possibility of this source from CDOM in river and estuarine systems and concluded that this pathway is significant only under anoxia in the presence of added methyl radical precursor (acetone). By irradiating water samples under simulated sunlight and then measuring the increase rate of $\left[\mathrm{CH}_{4}\right]$ with prolonged irradiation time, Zhang and Xie (2015) found that photomethanification in river water occurred under both suboxic and oxic conditions, with the rate under suboxic conditions being 7-8 times higher than that under oxic conditions, and that an addition of micromolar levels of methyl radical precursor (DMS) greatly accelerated this process. However, no information is yet available on the photoproduction of $\mathrm{CH}_{4}$ in the Bohai Sea. Considering the almost saturated DO level (averaged 104.1 $\pm 10.7 \%$ ) and nanomolar levels of DMS (11.9 to $\left.27.6 \mathrm{nmol} \mathrm{\textrm {L } ^ { - 1 }}\right)$ and DMSP (dissolved plus particulate ranging from 40.6 to $64.0 \mathrm{nmol}$ $\mathrm{L}^{-1}$ ) in the surface Bohai Sea in summer (Yang et al., 2014), photoproduction may contribute only marginally to the surface $\left[\mathrm{CH}_{4}\right]$ and thus can be ignored in this study so as to simplify our model.

\section{Modeling for Stations 29 and 30 Within the Type I Area}

Due to technical limitations, we did not measure the strengths of methanogenesis and methanotrophy individually. However, their relative strengths in each layer can be derived from the net $\mathrm{CH}_{4}$ cycling rates (refer to Section "Net $\mathrm{CH}_{4}$ Cycling Rates"), which indicated that in situ methanogenesis was almost balanced by methanotrophy in the surface layer but overbalanced by the latter in the bottom layer. Our incubation results were different from the earlier results reported by Ye et al. (2016), who observed $\left[\mathrm{CH}_{4}\right]$ increases during their bottom-water incubations in the East China Sea. The latter were collected from a hypoxic area off the Changjiang Estuary with DO values of less than $2 \mathrm{mg}$ $\mathrm{L}^{-1}$. This is much different from our environmental settings with DO values of $4.11 \mathrm{mg} \mathrm{L}^{-1}$ at station 29 and $3.92 \mathrm{mg} \mathrm{L}^{-1}$ at station 30. High DO tends to increase the $\mathrm{CH}_{4}$ oxidation rate and to decrease the rate of methanogenesis in the water column. However, the difference may also potentially be attributable to different compositions of the local microbial community - the relative cell abundances of methanotrophs and methanogens may be different in the two sea areas, which deserves further investigations in the future.

Assuming a relatively steady state, which means that depthintegrated $\left[\mathrm{CH}_{4}\right]$ in each layer changes little over time (i.e., both $\Delta\left[\mathrm{CH}_{4}\right]_{\text {surf }}$ and $\Delta\left[\mathrm{CH}_{4}\right]_{\text {bott }}$ equal zero), equation (5) can be revised as $T=F$, and equation (6) can be revised as

$$
\begin{gathered}
R=(\text { Methanotrophy })_{\text {bott }}-(\text { methanogenesis })_{\text {bott }}+T, \text { or } \\
R=(\text { depth-integrated net cycling rate })_{\text {bott }}+F
\end{gathered}
$$

The depth of the bottom layer at each station was calculated as total water depth minus mixed-layer depth. As salinity was vertically homogenous in this study, the mixed-layer depth was derived based on temperature criteria, i.e., the depth at which the temperature was $0.5^{\circ} \mathrm{C}$ lower than the sea surface temperature.

The release rates of $\mathrm{CH}_{4}$ from the seafloor derived from equation (7) are presented in Table 2. The results showed that the seafloor released $\mathrm{CH}_{4}$ at a rate of $56.0 \mu \mathrm{mol} \mathrm{m} \mathrm{m}^{-2} \mathrm{~d}^{-1}$ and $60.8 \mu \mathrm{mol} \mathrm{m} \mathrm{m}^{-1}$ at stations 29 and 30, respectively. These values were higher than those observed in the outer Changjiang Estuary (1.9-2.4 $\mu \mathrm{mol} \mathrm{m} \mathrm{m}^{-2} \mathrm{~d}^{-1}$ ), which were derived from the incubation of sediment cores (Zhang, 2004). However, our results were at the lower end of the range obtained on the shelf of the Black Sea $\left(36-271 \mu \mathrm{mol} \mathrm{m} \mathrm{m}^{-2} \mathrm{~d}^{-1}\right)$, which were calculated from independent estimates of methane production and oxidation rates in the sediment (Ivanov et al., 2002). Table 2 also shows that only $7 \%$ of the $\mathrm{CH}_{4}$ released from seafloor escaped through the water column into the atmosphere, implying that $93 \%$ of the $\mathrm{CH}_{4}$ released from the seafloor was microbially consumed in the water column. This ratio of integrated oxidation rate to sea-to air flux $(93: 7=13.3)$ fell into the range of 2.5-19.0 in the Baltic Sea during the stratified season (Steinle et al., 2017), in line with the previous findings that microbial oxidation usually predominates over gas exchange as sinks of $\mathrm{CH}_{4}$ in an oxygenated water column (Kessler et al., 2011; Zhang and Zhai, 2015).

Based on the model presented in Figure 6, the turnover time of $\mathrm{CH}_{4}(\tau)$ in the surface layer can be estimated as $\mathrm{CH}_{4}$ content $\left(\left[\mathrm{CH}_{4}\right]_{\text {surf }} \times\right.$ mixed-layer depth) divided by $F$ and $\tau$ in the bottom layer as $\mathrm{CH}_{4}$ content $\left(\left[\mathrm{CH}_{4}\right]_{\text {bott }} \times\right.$ bottom-layer depth) divided by $R$. Thus, $\tau_{\text {surf }}$ was calculated to be 10.1 days at station 29 and 9.0 days at station 30 , while $\tau_{\text {bott }}$ was calculated to be 48.4 days at station 29 and 49.2 days at station 30 . $\tau_{\text {bott }}$ was five times longer than $\tau_{\text {surf, }}$, partially explaining why bottomwater $\left[\mathrm{CH}_{4}\right]$ was usually higher than surface $\left[\mathrm{CH}_{4}\right]$ in the central Bohai Sea.

\begin{tabular}{|c|c|c|c|c|c|}
\hline Station & $\begin{array}{c}\text { Net loss rate } \\
\left(\mathrm{nmol} \mathrm{kg}{ }^{-1} \mathrm{~h}^{-1}\right)\end{array}$ & $\begin{array}{l}\text { Depth of bottom } \\
\text { layer }(\mathrm{m})\end{array}$ & $\begin{array}{l}\text { Depth-integrated net loss } \\
\text { rate }\left(\mu \mathrm{mol} \mathrm{m} \mathrm{m}^{-2} \mathrm{~d}^{-1}\right)\end{array}$ & 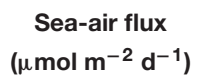 & $\begin{array}{l}\text { Sedimentary release } \\
\qquad\left(\mu \mathrm{mol} \mathrm{m}{ }^{-2} \mathrm{~d}^{-1}\right)\end{array}$ \\
\hline 29 & 0.124 & 15.90 & 52.3 & 3.70 & 56.0 \\
\hline
\end{tabular}

TABLE 2 | Sources and sinks of $\mathrm{CH}_{4}$ at stations 29 and 30.

a Calculated as total water depth minus mixed-layer depth. ${ }^{b}$ Calculated as depth-integrated net loss rate plus sea-air flux (refer to Section "Three Types of CH4 Sources From Seafloor" for model description). 


\section{$\mathrm{CH}_{4}$ Dynamics Regulated by Stratification and [DO]}

With a higher resolution, the vertical profile of $\left[\mathrm{CH}_{4}\right]$ at station 02 exhibited a strong concentration gradient across the thermocline (Figure 3a), indicating that stratification acted as a barrier preventing the upward transportation of dissolved $\mathrm{CH}_{4}$ from the bottom layer to the surface layer. This result is in line with the much longer turnover time of $\mathrm{CH}_{4}$ in the bottom layer than in the surface layer at stations 29 and 30 (see section "Modeling for Stations 29 and 30 Within the Type I Area"). Moreover, the plot of averaged SR in the bottom water at each station vs. $\log _{10} \varphi$ of the water column (Figure 5B) shows that averaged SR is positively correlated with the degree of stratification $\left(\mathrm{SR}=288.11 \times \log _{10} \varphi+95.39, r=0.406, n=35\right.$, $p<0.05)$. By summarizing $\left[\mathrm{CH}_{4}\right]_{\text {bott }}$ in this study and the previous studies (Table 3), we find that $\left[\mathrm{CH}_{4}\right]_{\text {bott }}$ is always higher in stratified seasons $\left(9.1-17.1 \mathrm{nmol} \mathrm{\textrm {L } ^ { - 1 }}\right.$ in summer and early autumn) than in other seasons $\left(4.6-7.5 \mathrm{nmol} \mathrm{L}^{-1}\right)$. This suggests that $\mathrm{CH}_{4}$ dynamics in the central Bohai Sea are highly regulated by the seasonal variation of stratification and the subsequent covariation of DO.

Once the water column is stratified in summer, both upward transport of $\mathrm{CH}_{4}$ and downward migration of $\mathrm{DO}$ are hampered (as reflected in Figure 3a). A similar scenario has been reported in the stratified basins of the Baltic Sea (Schmale et al., 2010b), Black Sea (Schmale et al., 2010a) and North Sea (Sommer et al., 2015). In bottom waters, DO will be gradually consumed by community respiration (as discussed in Section "Hydrological and Metabolic Settings"). The decreased DO will tip the competitive advantage away from methanotrophy and toward methanogenesis, leading to a buildup of $\mathrm{CH}_{4}$. Moreover, the increased $\left[\mathrm{CH}_{4}\right]$ in bottom waters might foster a bacterial bloom (for example, in the case in the Gulf of Mexico reported by Kessler et al., 2011). Therefore, bottom-water $\mathrm{CH}_{4}$ could be maintained in a dynamic steady state with high concentrations (Table 3).

If the stratification is episodically disturbed (e.g., by sea gales), the $\mathrm{CH}_{4}$ store in bottom waters will be rapidly vented into

\begin{tabular}{|c|c|c|c|c|}
\hline Winter & Spring & Summer & Autumn & References \\
\hline & & $\begin{array}{c}9.9 \pm 8.2 \\
\text { (August- } \\
\text { September } \\
\text { 2008) }\end{array}$ & & Li et al., 2010 \\
\hline & & $\begin{array}{c}9.1 \pm 2.5 \\
\text { (August 2012) }\end{array}$ & & Zhang et al., 2014 \\
\hline & & $\begin{array}{c}14.2 \pm 7.2 \\
\text { (August 2014) }\end{array}$ & $\begin{array}{c}4.6 \pm 2.9 \\
\text { (November 2014) }\end{array}$ & Zang, 2018 \\
\hline & $\begin{array}{c}7.5 \pm 2.8 \\
\text { (May 2015) }\end{array}$ & $\begin{array}{c}17.1 \pm 15.6 \\
\text { (August 2016) }\end{array}$ & $\begin{array}{c}4.9 \pm 3.1 \\
\text { (October 2016) }\end{array}$ & Zang, 2018 \\
\hline \multirow[t]{2}{*}{$\begin{array}{l}6.4 \pm 3.9 \\
\text { (February } \\
2017 \text { ) }\end{array}$} & $\begin{array}{c}6.0 \pm 4.7 \\
\text { (May 2017) }\end{array}$ & & $\begin{array}{c}9.8 \pm 4.1^{\mathrm{a}} \\
\text { (September } \\
\text { 2017) }\end{array}$ & Zang, 2018 \\
\hline & & $\begin{array}{c}9.6 \pm 5.7 \\
\text { (August 2018) }\end{array}$ & & This study \\
\hline
\end{tabular}

${ }^{a}$ A collapsing thermocline was observed during this early autumn survey. the atmosphere. At the same time, the water column can be reoxygenated (Zhai et al., 2019), and the aerobic $\mathrm{CH}_{4}$ oxidation will resume at a relatively high rate. This hypothesis can explain why $\mathrm{CH}_{4}$ showed a net loss in the oxygenated bottom water in this study (Figure 4), whereas it showed a net increase in hypoxic bottom waters in the East China Sea (Ye et al., 2016). In this sense, this study presents a snapshot of $\mathrm{CH}_{4}$ dynamics in the central Bohai Sea shortly after summertime stratification was broken by typhoon events (i.e., Ampil, Yagi and Rumbia in summer 2018 3 ).

In general, water column stratification limited vertical gas exchange between the surface and bottom layers, leading to $\mathrm{CH}_{4}$ accumulation and DO-deficiency in bottom water. On the one hand, the increased $\left[\mathrm{CH}_{4}\right]$ and decreased DO level can lead to feedback involving the microbial community that tends to maintain $\mathrm{CH}_{4}$ at a steady state; on the other hand, episodic or seasonal breakdown of summertime stratification could cause part of the stored $\mathrm{CH}_{4}$ in the bottom waters to be emitted to the atmosphere. Thus, the sea-to-air $\mathrm{CH}_{4}$ flux in the central Bohai Sea is supposed to be episodically enhanced due to substantial perturbation by storm events during the stratified period and seasonally enhanced due to breakdown of the thermocline in the mid-autumn.

\section{CONCLUSION}

$\left[\mathrm{CH}_{4}\right]$ showed vigorous spatial variation in the water column of the central Bohai Sea in summer 2018. This variation was caused by $\mathrm{CH}_{4}$ release from three types of seafloor sources. These release types can be identified by different relationships between $\mathrm{CH}_{4}$ and DO in the water column. This approach may have applicability in many other coastal systems with similar biogeochemical and geological conditions.

Net $\mathrm{CH}_{4}$ loss within bottom water was probably related to a high DO level, which promotes methanotrophy and inhibits methanogenesis. In this study, $>90 \%$ of the $\mathrm{CH}_{4}$ released from the seafloor is microbially consumed in the water column, leaving only $<10 \%$ to escape through the water column into the atmosphere. To better interpret the dynamics of $\mathrm{CH}_{4}$ in the Bohai Sea, more processes need to be quantified independently, such as in situ $\mathrm{CH}_{4}$ production (microbial vs. photochemical process), microbial $\mathrm{CH}_{4}$ consumption, and $\mathrm{CH}_{4}$ release from different types of seafloors in the central Bohai Sea.

\section{DATA AVAILABILITY STATEMENT}

All datasets generated for this study are included in the article/supplementary material.

\section{AUTHOR CONTRIBUTIONS}

$\mathrm{YZ}$ and $\mathrm{WZ}$ designed the experiments and prepared the manuscript. $\mathrm{YZ}$ and $\mathrm{BC}$ operated the experiments.

\footnotetext{
${ }^{3}$ http://agora.ex.nii.ac.jp/digital-typhoon/
} 


\section{FUNDING}

This work was jointly supported by the State Key R\&D project of China (Grant No. 2016YFA0601103), the National Natural Science Foundation of China (Grant No. 91751207), and the Fundamental Research Funds of Shandong University.

\section{REFERENCES}

Bange, H. W., Bartell, U. H., Rapsomanikis, S., and Andreae, M. O. (1994). Methane in the Baltic and North Seas and a reassessment of the marine emissions of methane. Global Biogeochem. Cy. 8, 465-480. doi: 10.1029/94GB02181

Bange, H. W., Bergmann, K., Hansen, H. P., Kock, A., Koppe, R., Malien, F., et al. (2010). Dissolved methane during hypoxic events at the Boknis Eck time series station (Eckernförde Bay, SW Baltic Sea). Biogeosciences 7, 1279-1284. doi: 10.5194/bg-7-1279-2010

Bange, H. W., and Uher, G. (2005). Photochemical production of methane in natural waters: implications for its present and past oceanic source. Chemosphere 58, 177-183. doi: 10.1016/j.chemosphere.2004.06.022

Benson, B. B., and Krause, D. (1984). The concentration and isotopic fractionation of oxygen dissolved in fresh water and seawater in equilibrium with the atmosphere. Limnol. Oceanogr. 29, 620-632. doi: 10.4319/lo.1984.29.3.0620

Bi, C. C. (2013). A Numerical Study on the Seasonal Variability and Dynamic Mechanism of Circulation in the Bohai Sea. Master Dissertation, Ocean University of China, Qingdao 1-79.

Boles, J. R., Clark, J. F., Leifer, I., and Washburn, L. (2001). Temporal variation in natural methane seep rate due to tides, coal oil point area, California. J. Geophys. Res. 106, 27077-27086. doi: 10.1029/2000JC000774

Borges, A. V., Champenois, W., Gypens, N., Delille, B., and Harlay, J. (2016). Massive marine methane emissions from near-shore shallow coastal areas. Sci. Rep. 6:27908. doi: 10.1038/srep27908

Damm, E., Kiene, R. P., Schwarz, J., Falck, E., and Dieckmann, G. (2008). Methane cycling in Arctic shelf water and its relationship with phytoplankton biomass and DMSP. Mar. Chem. 109, 45-59. doi: 10.1016/j.marchem.2007.12.003

Damm, E., Thoms, S., Beszczynska-Möller, A., Nöthig, E. M., and Kattner, G. (2015). Methane excess production in oxygen-rich polar water and a model of cellular conditions for this paradox. Polar Sci. 9, 327-334. doi: 10.1016/j.polar. 2015.05.001

Dickson, A. G. (1990). Standard potential of the reaction: $\mathrm{AgCl}(\mathrm{s})+1 / 2 \mathrm{H} 2(\mathrm{~g})$ $=\mathrm{Ag}(\mathrm{s})+\mathrm{HCl}(\mathrm{aq})$, and the standard acidity constant of the ion HSO4- in synthetic sea water from 273.15 to 318.15 K. J. Chem. Thermodyn. 22, 113-127. doi: 10.1016/0021-9614(90)90074-Z

Dickson, A. G., Sabine, C. L., and Christian, J. R. (2007). Guide to best Practices for Ocean CO2 Measurements. Japan: PICES Special Publication., 3.

Gu, P. P., Zhang, G. L., Li, P. P., Han, Y., and Zhao, Y. C. (2011). Effect of the watersediment regulation on dissolvled methane in the lower Yellow River estuary and its adjacent marine area. China Environ. Scie. 31, 1821-1828.

Guan, B. (1994). "Patterns and structures of the currents in Bohai, Huanghai and East China Seas," in Oceanology of China Seas, eds D. Zhou, Y. Liang, and C. Zeng (Dordrecht: Kluwer Academic Publishers), 17-26. doi: 10.1007/978-94011-0862-1_3

Hanson, R. S., and Hanson, T. E. (1996). Methanotrophic bacteria. Microbiol. Rev. 60, 439-471. doi: 10.1128/mmbr.60.2.439-471.1996

Huang, D. J., Su, J. L., and Backhaus, J. O. (1999). Modelling the seasonal thermal stratification and baroclinic circulation in the Bohai Sea. Cont. Shelf Res. 19, 1485-1505. doi: 10.1016/S0278-4343(99)00026-6

IPCC, (2013). Climate Change 2013: The Physical Science Basis. Contribution of Working Group I to the Fifth Assessment Report of the Intergovernmental Panel on Climate Change. Cambridge: Cambridge University Press.

Ivanov, M. V., Pimenov, N. V., Rusanov, I. I., and Lein, A. Y. (2002). Microbial processes of the methane cycle at the north western shelf of the Black Sea. Estuar. Coast. Shelf Sci. 54, 589-599. doi: 10.1006/ecss.2000.0667

Karl, D. M., Beversdorf, L., Bjorkman, K. M., Church, M. J., Martinez, A., and DeLong, E. F. (2008). Aerobic production of methane in the sea. Nat. Geosci. 1, 473-478. doi: 10.1038/ngeo234

\section{ACKNOWLEDGMENTS}

We thank Shu Yang and the crew of the R/V Haili for assistance in the collection of field samples. Tian-qi Xiong and Song-yin Wang provided much help during the data collection of the carbonate system. We are also grateful to the two reviewers for their constructive comments.

Karl, D. M., and Tilbrook, B. D. (1994). Production and transport of methane in oceanic particulate organic matter. Nature 368, 732-734. doi: 10.1038/368732a0

Kessler, J. D., Valentine, D. L., Redmond, M. C., Du, M., Chan, E. W., Mendes, S. D., et al. (2011). A persistent oxygen anomaly reveals the fate of spilled methane in the deep Gulf of Mexico. Science 331, 312-315. doi: 10.1126/science.1199697

Kirschke, S., Bousquet, P., and Ciais, P. (2013). Three decades of global methane sources and sinks. Nat. Geosci. 6, 813-823. doi: 10.1038/NGEO1955

Knap, A., Michaels, A., Close, A., Ducklow, H., and Dickson, A. (1996). Protocols for the Joint Global Ocean Flux Study (JGOFS) Core Measurements. JGOFS Report No.19. Paris: UNESCO.

Li, P. P., Zhang, G. L., Zhao, Y. C., and Liu, S. M. (2010). Study on distributions and flux of methane dissolved in the Bohai Sea in summer. Adv. Mar. Sci. 28, $478-487$.

Li, Y. F., Wolanski, E., and Zhang, H. (2015). What processes control the net currents through shallow straits? A review with application to the Bohai Strait, China. Estuar. Coast. Shelf Sci. 158, 1-11. doi: 10.1016/j.ecss.2015.03.013

Liss, P. S., and Slater, P. G. (1974). Flux of gases across the air-sea interface. Nature 247, 181-184. doi: 10.1038/247181a0

Liu, Z. X., Xia, D. X., Berne, S., Wang, K. Y., Marsset, T., Tang, Y. X., et al. (1998). Tidal deposition systems of China's continental shelf, with special reference to the eastern Bohai Sea. Mar. Geol. 145, 225-253. doi: 10.1016/S0025-3227(97) 00116-3

Mau, S., Blees, J., Helmke, E., Niemann, H., and Damm, E. (2013). Vertical distribution of methane oxidation and methanotrophic response to elevated methane concentrations in stratified waters of the Arctic fjord Storfjorden (Svalbard, Norway). Biogeosciences 10, 6267-6278. doi: 10.5194/bg-10-62672013

Metcalf, W. W., Griffin, B. M., Cicchillo, R. M., Gao, J., Janga, S. C., Cooke, H. A., et al. (2012). Synthesis of methylphosphonic acid by marine microbes: a source for methane in the aerobic ocean. Science 337, 11104-11107. doi: $10.1126 /$ science. 1219875

Millero, F. J., Graham, T. B., Huang, F., Bustos-Serrano, H., and Pierrot, D. (2006). Dissociation constants of carbonic acid in seawater as a function of salinity and temperature. Mar. Chem. 100, 80-94. doi: 10.1016/j.marchem.2005.12.001

Murrell, J. C. (2010). “The aerobic methane oxidizing bacteria (Methanotrophs)," in Handbook of Hydrocarbon and Lipid Microbiology, ed. K. N. Timmis (Berlin: Springer), 1953-1966. doi: 10.1007/978-3-540-77587-4_143

Naqvi, S. W. A., Bange, H. W., Farías, L., Monteiro, P. M. S., Scranton, M. I., and Zhang, J. (2010). Marine hypoxia/anoxia as a source of $\mathrm{CH}_{4}$ and $\mathrm{N}_{2} \mathrm{O}$. Biogeosciences 7, 2159-2190. doi: 10.5194/bg-7-2159-2010

Pelletier, G. J., Lewis, E., and Wallace, D. W. R. (2015). CO2SYS.XLS: A Calculator for the CO2 System in Seawater for Microsoft Excel/VBA, Version 24. Olympia: Washington State Department of Ecology.

Reeburgh, W. S. (2007). Oceanic methane biogeochemistry. Chem. Rev. 107, 486-513. doi: 10.1021/cr050362v

Rhee, T. S., Kettle, A. J., and Andreae, M. O. (2009). Methane and nitrous oxide emissions from the ocean: a reassessment using basin-wide observations in the Atlantic. J. Geophy. Res. 114:D12304. doi: 10.1029/2008JD011662

Saunois, M., Bousquet, P., Poulter, B., Peregon, A., Ciais, P., Canadell, J. G., et al. (2016). The global methane budget 2000-2012. Earth Syst. Sci. Data 8, 697-751. doi: 10.5194/essd-8-697-2016

Schmale, O., Beaubien, S. E., Rehder, G., Greinert, J., and Lombardi, S. (2010a). Gas seepage in the Dnepr paleo-delta area (NW-Black Sea) and its regional impact on the water column methane cycle. J. Mar. Syst. 80, 90-100. doi: 10.1016/j.jmarsys.2009.10.003

Schmale, O., Schneider von Deimling, J., Gülzow, W., Nausch, G., Waniek, J. J., and Rehder, G. (2010b). Distribution of methane in the water column of the Baltic Sea. Geophys. Res. Lett. 37:L12604. doi: 10.1029/2010GL043115 
Shirodkar, G., Naqvi, S. W. A., Naik, H., Pratihary, A. K., Kurian, S., and Shenoy, D. M. (2018). Methane dynamics in the shelf waters of the west coast of India during seasonal anoxia. Mar. Chem 203, 55-63. doi: 10.1016/j.marchem.2018. 05.001

Simpson, J. H. (1981). The shelf-sea fronts: implications of their existence and behavior. Philos. Trans. R. Soc. Lond. Ser. A Math. Phys. Sci. 302, 531-543. doi: 10.1098/rsta.1981.0181

Sommer, S., Schmidt, M., and Linke, P. (2015). Continuous inline mapping of a dissolved methane plume at a blowout site in the Central North Sea UK using a membrane inlet mass spectrometer - Water column stratification impedes immediate methane release into the atmosphere. Mar. Petrol. Geol. 68, 766-775. doi: 10.1016/j.marpetgeo.2015.08.020

Steinle, L., Maltby, J., Treude, T., Kock, A., Bange, H. W., Engbersen, N., et al. (2017). Effects of low oxygen concentrations on aerobic methaneoxidation in seasonally hypoxic coastal waters. Biogeosciences 14, 1631-1645. doi: 10.5194/ bg-14-1631-2017

Sun, M. S., Zhang, G. L., Ma, X., Cao, X. P., Mao, X. Y., Li, J., et al. (2018). Dissolved methane in the East China sea: distribution, seasonal variation and emission. Mar. Chem. 202, 12-26. doi: 10.1016/j.marchem.2018.03.001

Tilbrook, B. D., and Karl, D. M. (1995). Methane sources, distributions and sinks from California coastal waters to the oligotrophic North Pacific gyre. Mar. Chem. 49, 51-64. doi: 10.1016/0304-4203(94)00058-L

Wang, B. C., Liu, F. H., Zheng, S. L., and Hao, Q. Q. (2019). Trophic strategy of diverse methanogens across a river-to-sea gradient. J. Microbiol. 57, 470-478. doi: $10.1007 /$ s12275-019-8482-3

Wanninkhof, R. (2014). Relationship between wind speed and gas exchange over the ocean revisited. Limnol. Oceanogr. Methods 12, 351-362. doi: 10.4319/lom.2014.12.351

Wei, Q. S., Wang, B. D., Yao, Q. Z., Xue, L., Sun, J. C., Xin, M., et al. (2019). Spatiotemporal variations in the summer hypoxia in the Bohai Sea (China) and controlling mechanisms. Mar. Pollut. Bull. 138, 125-134. doi: 10.1016/j. marpolbul.2018.11.041

Weller, D. I., Law, C. S., Marriner, A., Nodder, S. D., Chang, F. H., Stephens, J. A., et al. (2013). Temporal variation of dissolved methane in a subtropical mesoscale eddy during a phytoplankton bloom in the southwest Pacific Ocean. Prog. Oceanogr. 116, 193-206. doi: 10.1016/j.pocean.2013.07.008

Wiesenburg, D. A., and Guinasso, N. L. Jr. (1979). Equilibrium solubilities of methane, carbon monoxide and hydrogen in water and seawater. J. Chem. Eng. Data 24, 356-360. doi: 10.1021/je60083a006

WMO. (2017). The state of greenhouse gases in the atmosphere based on global observations through 2016. WMO Greenhouse Gas Bull. 3, 1-8.

Xu, F. H., Liang, J. J., Xu, G. S., Yuan, H. F., and Liu, Y. (2018). Genetic mechanisms and distribution characteristics of overpressures in the Paleogene reservoirs of the Bohai Bay Basin, East China. Energ. Explor. Exploit. 36, 388-413. doi: $10.1177 / 0144598717739394$

Yang, G. P., Song, Y. Z., Zhang, H. H., Li, C. X., and Wu, G. W. (2014). Seasonal variation and biogeochemical cycling of dimethylsulfide (DMS) and dimethylsulfoniopropionate (DMSP) in the Yellow Sea and Bohai Sea. J. Geophysi. Res. Oceans 119, 8897-8915. doi: 10.1002/2014JC010373

Ye, W., Zhang, G., Zhu, Z., Huang, D., Han, Y., Wang, L., et al. (2016). Methane distribution and sea-to-air flux in the East China Sea during the summer of 2013: impact of hypoxia. Deep-Sea Res. Part II 124, 74-83. doi: 10.1016/j.dsr2. 2015.01.008

Zang, K. P. (2018). Seasonal Variations and Regulatory Mechanisms of Dissolved Methane Concentration and its Sea-to-Air Fluxes in the Seasonal Oxygen
Deficient Zones in Bohai Sea. PhD thesis, Nanjing University of Information Science \& Technology, Nanjing.

Zhai, W. D., Zhao, H. D., Su, J. L., Liu, P. F., Li, Y. W., and Zheng, N. (2019). Emergence of summertime hypoxia and concurrent carbonate mineral suppression in the central Bohai Sea, China. J. Geophys. Res. Biogeo. 124, 2768-2785. doi: 10.1029/2019JG005120

Zhai, W. D., Zhao, H. D., Zheng, N., and Xu, Y. (2012). Coastal acidification in summer bottom oxygen-depleted waters in northwestern-northern Bohai Sea from June to August in 2011. Chin. Sci. Bull. 57, 1062-1068. doi: 10.1007/ s11434-011-4949-2

Zhai, W. D., Zheng, N., Huo, C., Xu, Y., Zhao, H. D., Li, Y. W., et al. (2014). Subsurface $\mathrm{pH}$ and carbonate saturation state of aragonite on the Chinese side of the North Yellow Sea: seasonal variations and controls. Biogeosciences 11, 1103-1123. doi: 10.5194/bg-11-1103-2014

Zhang, G. L. (2004). Studies on Biogeochemistry of Dissolved Methane and Nitrous Oxide in the Coastal Waters of China. PhD thesis, Ocean University of China, Qingdao 40-41.

Zhang, Y., and Xie, H. (2015). Photomineralization and photomethanification of dissolved organic matter in Saguenay River surface water. Biogeosciences 12, 6823-6836. doi: 10.5194/bg-12-6823-2015

Zhang, Y., and Zhai, W. D. (2015). Shallow-ocean methane leakage and degassing to the atmosphere: triggered by offshore oil-gas and methane hydrate explorations. Front. Mar. Sci. 2:34. doi: 10.3389/fmars.2015. 00034

Zhang, Y., Zhao, H. D., Zhai, W. D., Zang, K. P., and Wang, J. Y. (2014). Enhanced methane emissions from oil and gas exploration areas to the atmosphere - The central Bohai Sea. Mar. Pollut. Bull. 81, 157-165. doi: 10.1016/j.marpolbul.2014. 02.002

Zhao, H. D., Kao, S. J., Zhai, W. D., Zang, K. P., Zheng, N., Xu, X. M., et al. (2017). Effects of stratification, organic matter remineralization and bathymetry on summertime oxygen distribution in the Bohai Sea, China. Cont. Shelf Res. 134, 15-25. doi: 10.1016/j.csr.2016.12.004

Zhou, F., Huang, D. J., Xue, H. J., Xuan, J. L., Yan, T., Ni, X. B., et al. (2017). Circulations associated with cold pools in the Bohai Sea on the Chinese continental shelf. Cont. Shelf Res. 137, 25-38. doi: 10.1016/j.csr.2017. 02.005

Zhu, Y., and Chang, R. (2000). Preliminary study of the dynamic origin of the distribution pattern of bottom sediments on the continental shelves of the Bohai Sea, Yellow Sea and East China Sea. Estuar. Coast. Shelf Sci. 51, 663-680. doi: 10.1006/ecss.2000.0696

Zindler, C., Bracher, A., Marandino, C. A., Taylor, B., Torrecilla, E., Kock, A., et al. (2013). Sulphur compounds, methane, and phytoplankton: interactions along a north-south transit in the western Pacific Ocean. Biogeosciences 10, 3297-3311. doi: $10.5194 /$ bg-10-3297-2013

Conflict of Interest: The authors declare that the research was conducted in the absence of any commercial or financial relationships that could be construed as a potential conflict of interest.

Copyright (c) 2020 Zhang, Chen and Zhai. This is an open-access article distributed under the terms of the Creative Commons Attribution License (CC BY). The use, distribution or reproduction in other forums is permitted, provided the original author(s) and the copyright owner(s) are credited and that the original publication in this journal is cited, in accordance with accepted academic practice. No use, distribution or reproduction is permitted which does not comply with these terms. 


\section{APPENDIX A}

\section{DO Saturation Versus $\mathrm{CO}_{2}$ Fugacity and Apparent Oxygen Utilization (AOU) Versus Excess DIC}

To reveal the metabolic status in the area under study, carbonate system parameters within the water column, namely, DIC and TAlk, were analyzed following Zhai et al. (2014). Briefly, unfiltered water samples were stored in $60-\mathrm{mL}$ borosilicate glass bottles (for DIC) and 140-mL high-density polyethylene bottles (for TAlk). Each sample was sterilized with $50-\mu \mathrm{L}$ saturated $\mathrm{HgCl}_{2}$ and then sealed with a screw cap. They were preserved at room temperature and allowed to settle before measurement. DIC was measured by infrared detection following acid extraction of a 0.9 -mL sample with a Kloehn ${ }^{\circledast}$ digital syringe pump. TAlk was determined by Gran acidimetric titration on a 15-mL sample with another Kloehn ${ }^{\circledast}$ digital syringe pump and detected using a precision $\mathrm{pH}$ meter and $\mathrm{Orion}^{\otimes}$ 8102BN Ross electrode. Both DIC and TAlk determinations referred to
Certificated Reference Materials from the laboratory of Andrew G. Dickson at a precision level of $\pm 2 \mu \mathrm{mol} \mathrm{kg}-1$ (Dickson et al., 2007; Zhai et al., 2014). Seawater $\mathrm{CO}_{2}$ fugacity $\left(f \mathrm{CO}_{2}\right)$ was calculated from DIC, TAlk, seawater temperature, and salinity, using the calculation program CO2SYS.xls version 24 (Pelletier et al., 2015). The dissociation constants used for carbonic acid were those determined by Millero et al. (2006), and the dissociation constant for the $\mathrm{HSO}_{4}{ }^{-}$ion was determined as per Dickson (1990). The phosphate and silicate concentrations required by the program were set to zero.

Air-equilibrated DIC (DIC equ, corresponding to an $f \mathrm{CO}_{2}$ value of $400 \mu \mathrm{atm}$ ) was calculated from field-measured seawater temperature, salinity, and TAlk values. The departure of DIC from DIC equ was defined as the excess DIC (ExcessDIC). Assuming the water starts in a fully saturated state and ignoring the effects of air-sea $\mathrm{CO}_{2}$ exchanges, water mixing, and $\mathrm{CaCO}_{3}$ precipitation/dissolution, an ExcessDIC $>0$ means net community respiration, while an ExcessDIC $<0$ implies net community production.
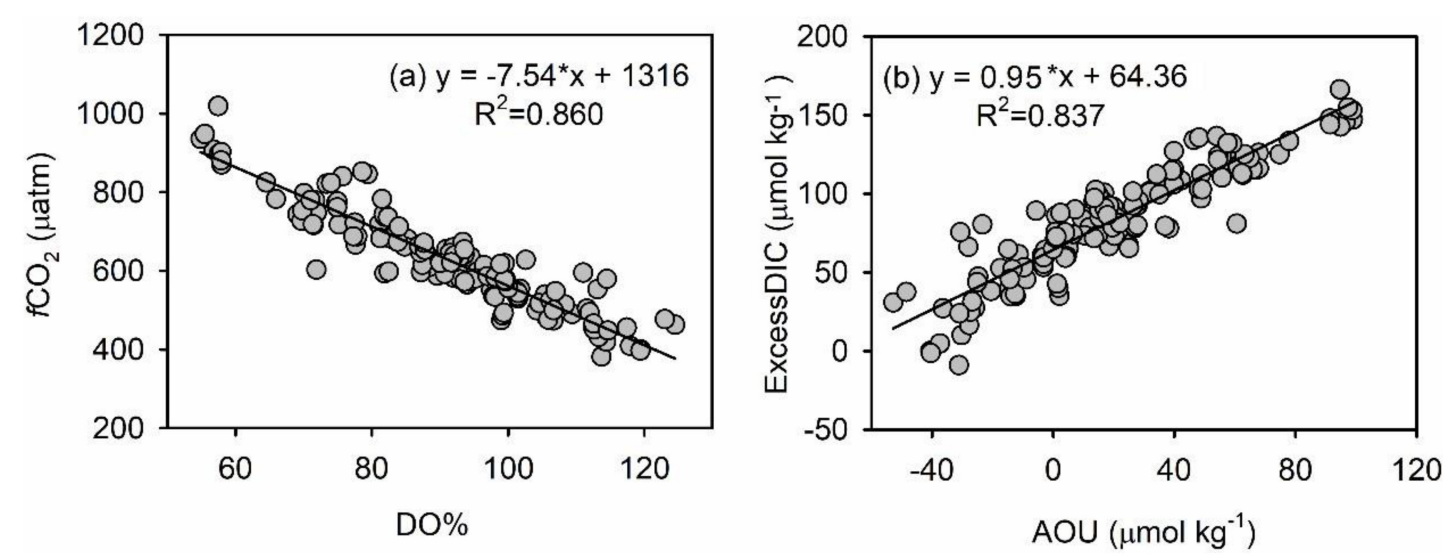

FIGURE A1 | Metabolic settings indicated by plots of $\mathrm{fCO}_{2}$ (matm) vs. DO\% (a) and Excess DIC $\left(\mu \mathrm{mol} \mathrm{kg}{ }^{-1}\right)$ vs. AOU ( $\left.\mu \mathrm{mol} \mathrm{O} 2 \mathrm{~kg}{ }^{-1}\right)$ (b). 


\section{APPENDIX B}

\section{$\mathrm{CH}_{4}$ and Hydrological Settings in the Adjacent North Yellow Sea}

To examine the possible impact of water exchanges between the Bohai Sea and the adjacent North Yellow Sea on distribution and budget of dissolved $\mathrm{CH}_{4}$, three reference stations were sampled along the Bohai Strait (out of the Bohai Sea). Vertical profiles of water temperature, salinity, and $\mathrm{CH}_{4}$ at these reference stations are presented in Figure B1.

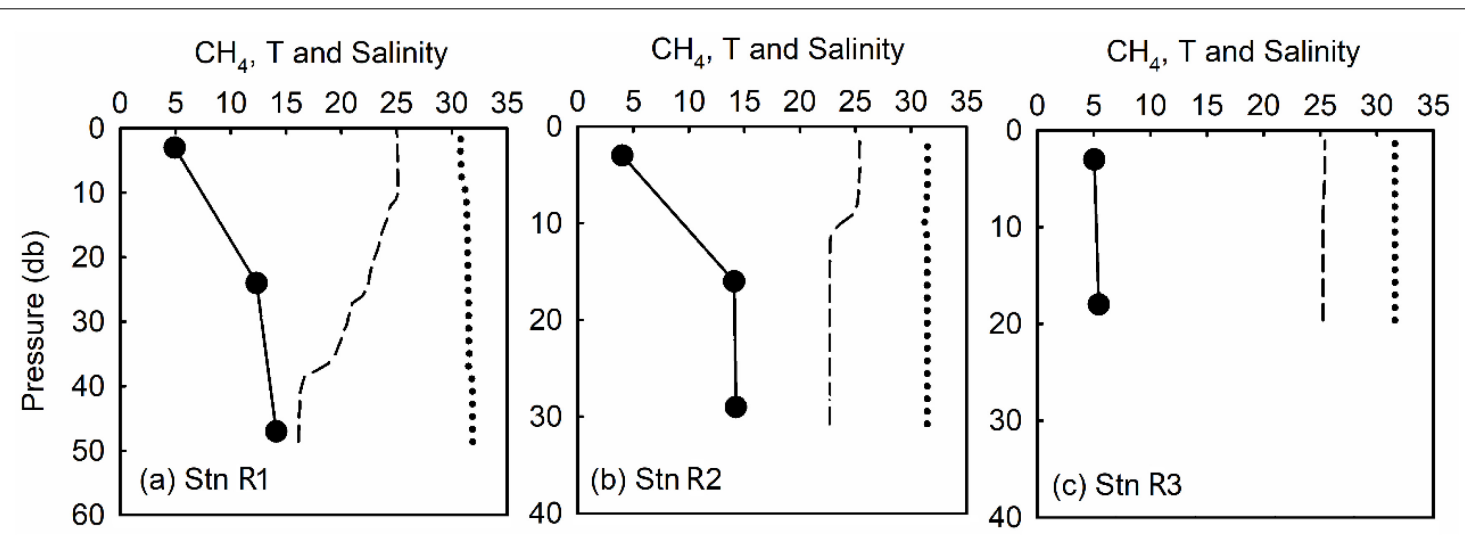

FIGURE B1 | Vertical profiles of $\left[\mathrm{CH}_{4}\right]$ (nmol kg ${ }^{-1}$, filled circles in black) (a), temperature $\left({ }^{\circ} \mathrm{C}\right.$, dashed lines) (b), and salinity (dotted lines) (c) at reference stations off the Bohai Strait. 